\title{
Optical Characterization of Europium-doped Indium Hydroxide Nanocubes Obtained by Microwave-Assisted Hydrothermal Method
}

\author{
Fabiana Villela da Motta*, Ana Paula de Azevedo Marques ${ }^{\mathrm{b}}$, Vinícius Dantas de Araújo ${ }^{\mathrm{a}}$ \\ Mara Tatiane de Souza Tavares ${ }^{\mathrm{a}}$,Mauricio Roberto Bomio Delmonte ${ }^{\mathrm{a}}$, Carlos Alberto Paskocimas , \\ Máximo Siu Lic, Rubens Maribondo do Nascimento ${ }^{\mathrm{a}}$, Elson Longo ${ }^{\mathrm{d}}$ \\ a Departamento de Engenharia de Materiais - DEMAT, Centro de Tecnologia - CT, \\ Universidade Federal do Rio Grande do Norte-UFRN, Av. Sen. Salgado Filho, 3000, \\ CEP 59072-970, Natal, RN, Brazil \\ ${ }^{\mathrm{b}}$ Universidade Federal de São Paulo - UNIFESP, Rua Prof. Artur Riedel, 275, \\ CEP 09972-270, Diadema, SP, Brasil \\ 'Instituto de Física de São Carlos - IFSC, Universidade de São Paulo - USP, \\ Av. Trabalhador São Carlense, 400, CEP 13566-590, São Carlos, SP, Brazil \\ ${ }^{\mathrm{d}}$ Laboratório Interdisciplinar de Eletroquímica e Cerâmica - LIEC, \\ Instituto de Química - IQ, Universidade Estadual Paulista - UNESP, \\ Rua Francisco Degni s/n, CEP 14801-907, Araraquara, SP, Brazil
}

Received: November 25, 2013; Revised: April 6, 2014

\begin{abstract}
Crystalline europium-doped indium hydroxide $\left(\mathrm{In}(\mathrm{OH})_{3}: \mathrm{Eu}\right)$ nanostructures were prepared by rapid and efficient Microwave-Assisted Hydrothermal (MAH) method. Nanostructures were obtained at low temperature. FE-SEM images confirm that these samples are composed of 3D nanostructures. XRD, optical diffuse reflectance and photoluminescence (PL) measurements were used to characterize the products. Emission spectra of europium-doped indium hydroxide ( $\mathrm{IH}: \mathrm{xEu}$ ) samples under excitation $(350.7 \mathrm{~nm})$ presented broad band emission regarding the indium hydroxide $(\mathrm{IH})$ matrix and ${ }^{5} \mathrm{D}_{0} \rightarrow{ }^{7} \mathrm{~F}_{0}$, ${ }^{5} \mathrm{D}_{0} \rightarrow{ }^{7} \mathrm{~F}_{1},{ }^{5} \mathrm{D}_{0} \rightarrow{ }^{7} \mathrm{~F}_{2},{ }^{5} \mathrm{D}_{0} \rightarrow{ }^{7} \mathrm{~F}_{3}$ and ${ }^{5} \mathrm{D}_{0} \rightarrow{ }^{7} \mathrm{~F}_{4}$ europium transitions at 582, 596, 618, 653 and $701 \mathrm{~nm}$, respectively. Relative intensities of $\mathrm{Eu}^{3+}$ emissions increased as the concentration of this ion increased from $0,1,2,4$ and $8 \mathrm{~mol} \%$, of $\mathrm{Eu}^{3+}$, but the luminescence is drastically quenched for the IH matrix.
\end{abstract}

Keywords: indium hydroxide, europium, Microwave-Assisted Hydrothermal, nanostructures

\section{Introduction}

Self-assembled micro-, meso- and nanostructures with specific morphology, novel properties and wide application potential in many fields are of great interest to chemists and material scientists due to their fundamental significance for addressing some basic issues of the quantum confinement effect and space-confined transport phenomena as well as their potential applications as advanced materials in functional nanodevices ${ }^{1}$.

Indium hydroxides, oxyhydroxides, and oxides are important semiconductor materials, which have attracted much attention in the past decade. Cubic $\operatorname{In}(\mathrm{OH})_{3}$, orthorhombic $\mathrm{InOOH}$, and cubic and hexagonal $\mathrm{In}_{2} \mathrm{O}_{3}$ are their common phases ${ }^{2} . \mathrm{In}(\mathrm{OH})_{3}$ is a wide-gap semiconductor with $\mathrm{Eg}=5.15 \mathrm{eV}$, with applications as a photocatalyst, among others ${ }^{3-5}$. $\mathrm{InOOH}(\mathrm{Eg}=3.5 \mathrm{eV})$ is also a typical widegap semiconductor ${ }^{6}$. Both cubic and hexagonal $\operatorname{In}_{2} \mathrm{O}_{3}$ are good n-type semiconductors with band gaps of 3.55-3.75 eV (which is close to that of $\mathrm{GaN}$ ), which have been widely used as solar cells ${ }^{7}$, transparent conductors ${ }^{8}$, and sensors ${ }^{2}$.

*e-mail: fabiana@ct.ufrn.br
Regarding indium hydroxide (IH), Shi et al. ${ }^{9}$ recently reported a IH truncated polyhedral microcrystal formation via conventional hydrothermal treatment at $180^{\circ} \mathrm{C}$ for $16 \mathrm{~h}$ and $18 \mathrm{~h}$ that showed PL spectrum with two emission peaks at 496.6 and $419.2 \mathrm{~nm}$ using excitation wavelength $(380 \mathrm{~nm}$ at room temperature). Yan et al. ${ }^{4}$ showed a broad band PL blue-green emission peak of IH nanocubes centered at $480 \mathrm{~nm}$.

Rare earth ions such as $\mathrm{Eu}^{3+}$ can be added to semiconductors to increase PL. Europium in its trivalent state is one of the most studied among rare earth ions by luminescence spectroscopy due to the simplicity of its spectra and wide application as red phosphor in color TV screens. This ion has also attracted significant research attention due to its potential application as biological sensors, phosphors, electroluminescent devices, optical amplifiers or lasers when used as doping in a variety of materials ${ }^{10,11}$. Dutta et al. ${ }^{12}$ showed $\mathrm{Eu}^{3+}$ and $\mathrm{Dy}^{3+}$ doped indium oxide nanoparticles synthesized by a sonochemical technique. $\mathrm{Eu}^{3+}$ transitions were observed after excitation at $235 \mathrm{~nm}$ which is possibly due to the highly strained and 
distorted environment around $\mathrm{Eu}^{3+}$ ions in the $\operatorname{In}_{2} \mathrm{O}_{3}$ lattice matrix.

Indium hydroxides with different morphology such as spheres $^{13}$, flowers ${ }^{14,15}$, cubes $^{16-22}$, rods ${ }^{23,24}$, etc., have been synthesized by several synthesis methods. The physical and chemical properties of these powders can be influenced by particle shape and size distribution, which depend on the synthesis method. Conventional hydrothermal synthesis has been used to obtain IH structures using a simple, practical and environmentally friendly method ${ }^{4,13,18}$.

Komarneni et al. ${ }^{25}$ proposed the use of microwave radiation in the hydrothermal system by promoting the development of a new technique offering reaction kinetic enhancement, formation of materials with different morphology, low synthesis temperature and reduced processing times. Recently, Microwave-Assisted Hydrothermal (MAH) method was successfully used to obtain $\mathrm{IH}^{[21]}$ and other oxides such as $\mathrm{ZnO}^{[26,27]}, \mathrm{BaTiO}_{3}{ }^{[28]}$ $\mathrm{CuO}^{[29]}, \mathrm{SrMoO}_{4}^{[30]}, \mathrm{CeO}_{2}{ }^{[31]}$ and $\mathrm{BaMoO}_{4}^{[32]}$.

In previous publications ${ }^{17,33}$, the synthesis and characterization of efficient luminescent indium hydroxides nanostructures, pure and doped with $\mathrm{Tb}^{3+}$, was described and it was verified that these materials are highly promising candidates for electronic and optical applications. Thus, studies on the effect of different rare earth dopants, such as $\mathrm{Eu}^{3+}$, on the synthesis and optical properties of indium hydroxide nanostructures synthesized by the MAH method are required to improve the scientific knowledge regarding future photoluminescent applications.

In this paper, we report the synthesis of $\operatorname{In}(\mathrm{OH})_{3}: \mathrm{Eu}$ (IH:xEu) nanostructures with concentrations of $\mathrm{x}=0,1$, 2, 4 and $8 \mathrm{~mol} \%$ of $\mathrm{Eu}^{3+}$ using the MAH method at a low temperature of $140^{\circ} \mathrm{C}$ for $30 \mathrm{~min}$. IH:Eu nanoarchitectures, the morphology and PL properties of these samples were investigated.

\section{Experimental Procedures}

Using the previously reported MAH method ${ }^{33}$, $\mathrm{In}(\mathrm{OH})_{3}: \mathrm{Eu}(\mathrm{IH}: \mathrm{xEu})$ powders were obtained. About 3.6 Mmol of Indium (III) chloride (99\% purity, Aldrich) and europium nitrate were dissolved in $80 \mathrm{~mL}$ of deionized water under constant stirring. Europium nitrate reagent was obtained by adding nitric acid to europium (III) oxide (Aldrich, USA, $99.999 \%$ ) at $70^{\circ} \mathrm{C} . \mathrm{Eu}^{3+}$ ion was added in the following percentages: $0,1,2,4$ and $8 \mathrm{~mol} \%$. The solution $\mathrm{pH}$ was adjusted to 10 by adding $\mathrm{NH}_{4} \mathrm{OH}$. After stirring for $10 \mathrm{~min}, 1 \mathrm{~mL}$ of polyethyleneglycol PEG ( $M \mathrm{w} 600)$ was added to the solution, and the mixture was then transferred to a Teflon autoclave. The system was sealed and placed in domestic microwave oven $(2.45 \mathrm{GHz}$, maximum power of $800 \mathrm{~W}$ ). The reaction system was heat treated at $140^{\circ} \mathrm{C}$ for $30 \mathrm{~min}$ (heating rate fixed at $25^{\circ} \mathrm{C} / \mathrm{min}$ ).

After MAH treatment, the white precipitate was washed with distilled water and dried at room temperature. The powders were characterized by X-ray diffraction (XRD) using Rigaku diffractometer (Model D/max-2500/PC) with $\mathrm{Cu} \mathrm{K} \alpha$ radiation. IH morphology and size were observed by field emission scanning electron microscopy (FE-SEM; Jeol JSM 6330F) images. UV-Vis reflectance spectra of IH powders were taken using Cary $5 \mathrm{G}$ equipment. PL spectra were measured using Thermal Jarrel-Ash Monospec 27 monochromator and Hamamatsu R446 photomultiplier. The $350.7 \mathrm{~nm}$ line of a krypton ion laser (Coherent Innova $90 \mathrm{~K}$ ) was used as the excitation source with output power of lasers kept at $200 \mathrm{~mW}$. All measurements were taken at room temperature.

\section{Results and Discussion}

The X-ray patterns of IH powders synthesized with different $\mathrm{Eu}^{3+}$ percentages at $140^{\circ} \mathrm{C}$ are presented in Figure 1a-e. Figure 1a shows that all diffraction peaks could be indexed to the cubic lattice [space group $\mathrm{Im}_{3}(204)$ ] to pure IH. With europium percentage increments (Figure 1b-e), the phases obtained by MAH treatment were basically IH with cubic structure (JCPDS card No. 16-0161) and the second phase in the InOOH formation with orthorhombic structure was observed [space group P21nm(31)] (JCPDS card No.71-2283).

The synthesis of $\mathrm{IH}$ and $\mathrm{InOOH}$ nanostructures is based on reactions ( 1 and 2$)^{34}$. Chen et al. ${ }^{35}$ reported that the $\mathrm{InOOH}$ phase and the morphology synthesized by ultrasound-assisted solvothermal route can be controlled by the choice of the alkaline media and also the solvent. The factors reported for the formation of InOOH hollow spheres synthesized by conventional hydrothermal method were temperature treatment, reaction time, reagents and solution $\mathrm{pH}^{6,36}$. We believe that the synthesis conditions are influenced by the use of europium nitrate as a source of $\mathrm{Eu}^{3+}$. The $\mathrm{pH}$ value of solutions decreased with increases in the europium nitrate concentration; therefore, larger amounts of $\mathrm{NH}_{4} \mathrm{OH}$ were used to obtain $\mathrm{pH}=10$, thus favoring the InOOH formation.

$\mathrm{In}^{3+}+3 \mathrm{H}_{2} \mathrm{O} \rightarrow \mathrm{In}(\mathrm{OH})_{3}+3 \mathrm{H}^{+}$

$\mathrm{In}(\mathrm{OH})_{3} \rightarrow \mathrm{InOOH}+\mathrm{H}_{2} \mathrm{O}$

To the best of our knowledge, the optical properties of IH:Eu have rarely been studied. Figure 2 shows the PL spectra of IH:xEu cube-like structures at room temperature. Efficient red emission can be observed when this matrix is doped with $\mathrm{Eu}^{3+}$, showing potential application for nanoarchitectures to serve as efficient red phosphor in luminescent nanodevices. Much effort has been dedicated to the study of PL in nanostructural materials since the first visible PL at room temperature was observed in porous silicon for the first time ${ }^{37}$. Rare ions are used to dope oxides not only as a probe to investigate local centers and energy ${ }^{38-40}$, but also to provoke changes in the optical behavior.

Optical diffuse reflectance measurements have been carried out on IH:xEu particles obtained under MAH conditions. An estimation of the optical band gap " $\mathrm{E}_{\text {gap }}$ " (Table 1) was obtained using the Wood \& Tauc method ${ }^{41}$. The calculated $\mathrm{E}_{\text {gap }}$ values were 5.12, 4.88, 3.63, 3.56 and $3.55 \mathrm{eV}$ for samples treated at $140^{\circ} \mathrm{C}$ for $30 \mathrm{~min}$, pure and with 1,2 , 4 and $8 \mathrm{~mol} \% \mathrm{Eu}^{3+}$, respectively. The $\mathrm{E}_{\text {gap }}$ reduction with increasing $\mathrm{Eu}^{3+}$ content can be associated with the formation of the InOOH phase. Zhu et al. ${ }^{6}$ studied InOOH hollow spheres synthesized by conventional hydrothermal method 


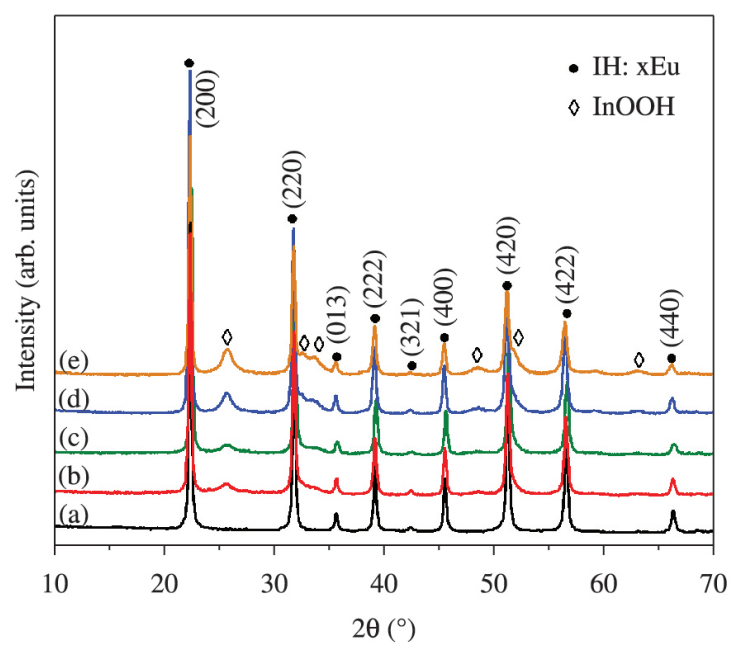

Figure 1. XRD patterns of IH:xEu powders obtained by the MAH method at $140^{\circ} \mathrm{C}$ for $30 \min$ : (a) $\mathrm{x}=0$, (b) $\mathrm{x}=1$, (c) $\mathrm{x}=2$, (d) $\mathrm{x}=4$ and (e) $\mathrm{x}=8 \mathrm{~mol} \%$.

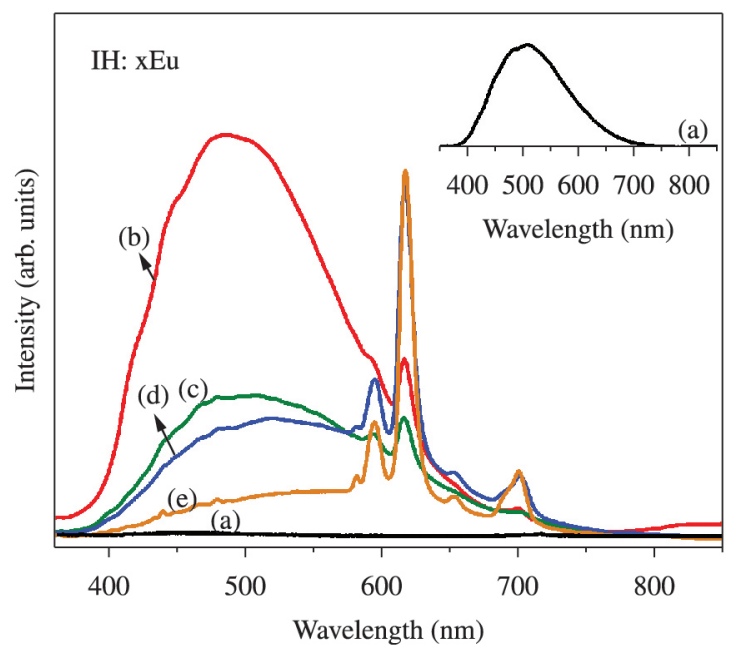

Figure 2. PL spectra of IH:xEu structures obtained by the MAH method at $140^{\circ} \mathrm{C}$ for 30 min: (a) $\mathrm{x}=0$, (b) $\mathrm{x}=1$, (c) $\mathrm{x}=2$, (d) $\mathrm{x}=4$ and (e) $\mathrm{x}=8 \mathrm{~mol} \%$.

Table 1. Optical band gap $\left(\mathrm{E}_{\text {gap }}\right)$ and fitting parameters of the Gaussian peaks for PL of the IH matrix obtained with excitation wavelength at $350.7 \mathrm{~nm}$.

\begin{tabular}{cccccc}
\hline IH:xEu & $\mathbf{E}_{\text {gap }}(\mathbf{e V})$ & \multicolumn{4}{c}{ Peak center (nm) } \\
\cline { 3 - 6 } & & $\mathbf{4 5 0}$ & $\mathbf{5 1 2}$ & $\mathbf{5 7 0}$ & $\mathbf{6 2 3}$ \\
\cline { 3 - 6 } & & $\boldsymbol{\%}^{\mathbf{a}}$ & $\boldsymbol{\%}^{\mathbf{a}}$ & $\boldsymbol{\%}^{\mathbf{a}}$ & $\boldsymbol{\%}^{\mathbf{a}}$ \\
\hline $\mathrm{X}=0$ & 5.12 & 18 & 55 & 13 & 14 \\
$\mathrm{X}=1$ & 4.88 & 29 & 49 & 14 & 8 \\
$\mathrm{x}=2$ & 3.63 & 25 & 31 & 26 & 18 \\
$\mathrm{X}=4$ & 3.56 & 21 & 19 & 27 & 33 \\
$\mathrm{x}=8$ & 3.55 & 11 & 18 & 39 & 32 \\
\hline
\end{tabular}

${ }^{\text {aPercentage obtained by dividing the area of each decomposed PL curves }}$ by the total PL area. and estimated that the optical band gap was $3.5 \mathrm{eV}$ and the $\mathrm{E}_{\text {gap }}$ value for crystalline $\mathrm{In}(\mathrm{OH})_{3}$ powders was $5.15 \mathrm{eV}^{[5]}$. Pure IH or IH:Eu belongs to n-type semi-conductors where oxygen vacancies can induce the formation of new energy levels in the band gap. The generation of oxygen defects in the crystalline structure of cube-like crystals of pure $\mathrm{IH}$ and $\mathrm{IH}: \mathrm{Eu}$ are apparent. The formation of $\mathrm{InOOH}$ during synthesis for samples with europium releases molecular water (reaction 2) and provides oxygen vacancies in the lattice. Thus, during the MAH process, the displacement of oxygen related to In or Eu modulates different species of trapped holes $\left(\mathrm{V}_{\mathrm{o}}, \mathrm{V}_{\mathrm{o}}^{\mathrm{x}}\right.$ and $\mathrm{V}_{\mathrm{o}} \cdot{ }^{*}$ species $)$ around $\left[\mathrm{InO}_{5} \mathrm{~V}_{\mathrm{o}}{ }^{\mathrm{x}}\right]$ clusters and gives rise to complex cluster vacancies ${ }^{26}$.

Emission spectra in Figure 2 were obtained under excitation of $350.7 \mathrm{~nm}$. The efficient sharp peak is attributed to ${ }^{5} \mathrm{D}_{0} \rightarrow{ }^{7} \mathrm{~F}_{\mathrm{j}}$ emission transition, indicating the presence of $\mathrm{Eu}^{3+}$ ion in the IH lattice. Emission spectra of IH:Eu structures exhibit an efficient red PL emission peak centered at around $618 \mathrm{~nm}$, corresponding to the forced electric dipole transition ${ }^{5} \mathrm{D}_{0} \rightarrow{ }^{7} \mathrm{~F}_{2}$ which is allowed in this particular case since europium does not occupy a symmetry center in the indium hydroxide. Another weaker emission at ${ }^{5} \mathrm{D}_{0} \rightarrow{ }^{7} \mathrm{~F}_{0}$. ${ }^{5} \mathrm{D}_{0} \rightarrow{ }^{7} \mathrm{~F}_{1}, \mathrm{D}_{0} \rightarrow{ }^{7} \mathrm{~F}_{3}$ and ${ }^{5} \mathrm{D}_{0} \rightarrow{ }^{7} \mathrm{~F}_{4}$ corresponding to $\mathrm{Eu}^{3+}$ transitions can be observed at around 582, 596, 653 and 701 nm, respectively ${ }^{42,43}$.

The relative intensities of $\mathrm{Eu}^{3+}$ emissions increase as the concentration of this ion increases from 1 to $8 \mathrm{~mol}$ $\%$; however the luminescent emission of the IH matrix is drastically quenched. When the $\mathrm{Eu}^{3+}$ concentration is higher, the mechanism that prevails is the energy transfer from the $\mathrm{IH}$ matrix to $\mathrm{Eu}^{3+}$. This energy migration process is responsible for the increase in $\mathrm{Eu}^{3+}$ luminescence ${ }^{43,44}$.

For Eu-doped inorganic materials, optical transitions occur mainly from ${ }^{5} \mathrm{D}_{0}$ to ${ }^{7} \mathrm{~F}_{\mathrm{J}}(0<\mathrm{J}<6)$ manifold, giving rise to a series of red emission lines with intensities depending on the local $\mathrm{Eu}^{3+}$ environment. From all possible transitions, only ${ }^{5} \mathrm{D}_{0} \rightarrow{ }^{7} \mathrm{~F}_{1}$ is magnetically dipole allowed in the free ion; all others require J-level mixing induced by the crystal field. Whereas the odd-parity components of the crystal field enable electric dipole transitions between ${ }^{5} \mathrm{D}_{0}$ and ${ }^{7} \mathrm{~F}_{2,46}$ in the first order, a combination of odd and even crystal-field terms gives rise to faint second-order transitions for the remaining $\mathrm{J}=0,3,5$ values. The intensities of the different $\mathrm{J}$ transitions, and in particular the hypersensitive $\mathrm{J}=2$ peak provide a good measure of the local crystal field acting on $\mathrm{Eu}^{3+}$ ions ${ }^{[45]}$.

Assuming the PL emission peaks can be described with a Gaussian function, the emission envelope in Figure 2 can be fitted to multiple peaks (Figure 3a-e). In the emission envelope from $\mathrm{IH}: \mathrm{xEu}$, each color represents a different type of electronic transition and can be linked to a specific structural arrangement ${ }^{46}$. To better understanding PL properties, the curves were analyzed using the PeakFit deconvolution software ${ }^{47}$. Based on the Gaussian line broadening mechanism for luminescence processes, the fine features in the PL spectra of the IH matrix were deconvoluted and extracted from deconvolution curves. Figure 3a-e illustrates such decompositions while Table 1 lists the areas under the curve of the respective transitions. 

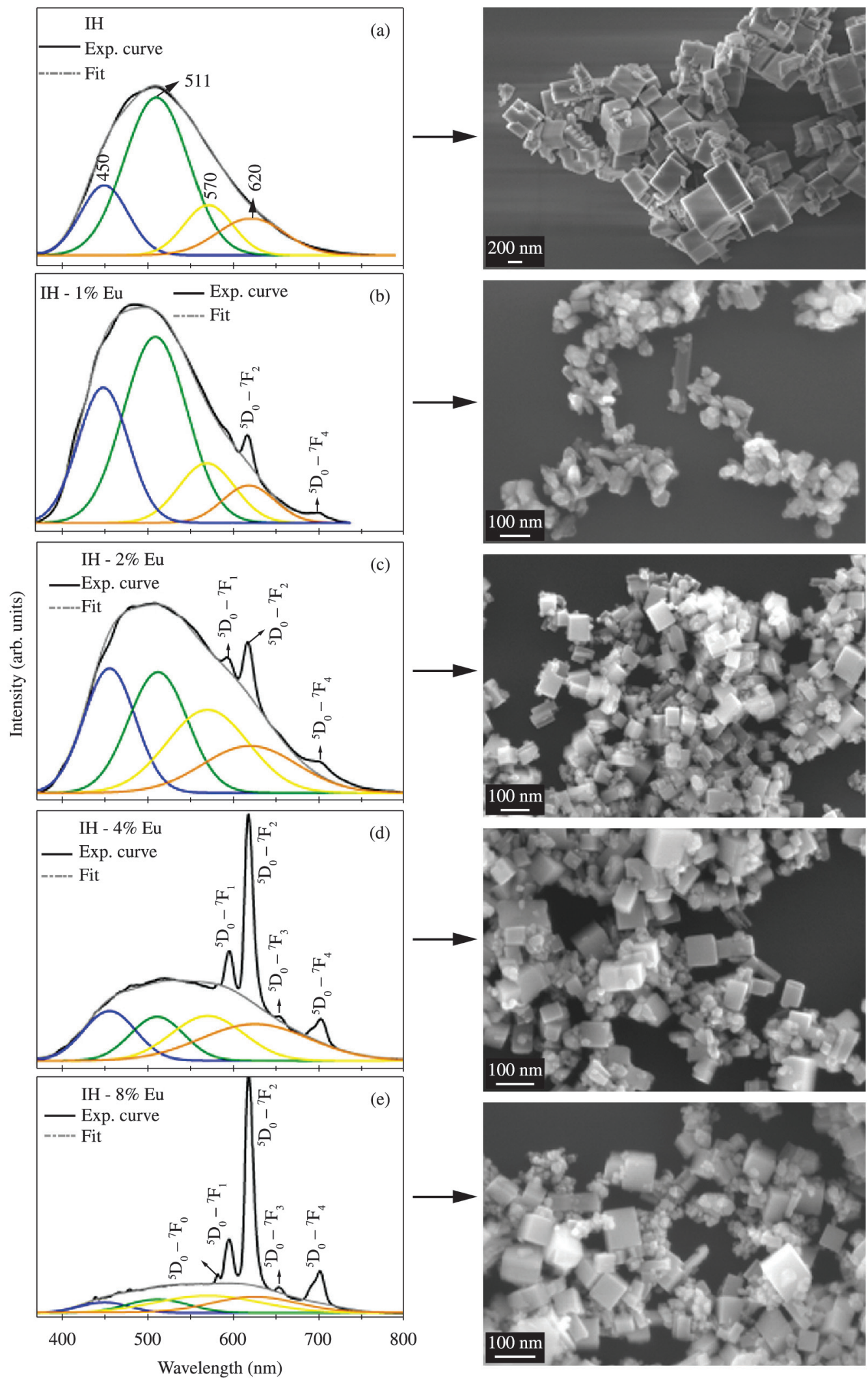

Figure 3. Deconvolution of a PL curve fitted for IH:xEu samples and respective Fe-SEM images (on the side): (a) $\mathrm{x}=0$, (b) $\mathrm{x}=1$, (c) $\mathrm{x}=2$, (d) $\mathrm{x}=4$ and (e) $\mathrm{x}=8 \mathrm{~mol} \%$.. 
The IH matrix PL curves for all samples are composed of four PL components with the following maxima $\mathrm{nm}$ : blue $=450 \mathrm{~nm}$, green $=512 \mathrm{~nm}$, yellow $=570 \mathrm{~nm}$ and orange $=623 \mathrm{~nm}$. The PL deconvolution shows the IH matrix ordered-to- disordered structure changing with the increase percentage in the $\mathrm{Eu}^{3+}$ ion which favors yellow and orange light emission (higher wavelength) for smaller energies. According to the calculated band gap values $\left(\mathrm{E}_{\text {gap }}\right)$, the increase percentage in the $\mathrm{Eu}^{3+}$ ion decreased the $\mathrm{E}_{\text {gap }}$ value and therefore increased the short-range disorder for clusters in the matrix. The appropriate structural disorder can result in better PL emission as compared with a completely ordered emission. Structurally disordered materials in general present oxygen vacancies, lattice defects, impurities and/ or local bond distortions which yield localized electronic levels in their band gap ${ }^{43}$. Figure 3a-e (on the side) depicts FE-SEM images of IH:xEu nanostructures obtained at $140^{\circ} \mathrm{C}$ for $30 \mathrm{~min}$. Figure $3 \mathrm{a}$ shows cubic and irregularlyshaped structures of pure IH with smooth and uniform surface where the angle between adjacent edges is relatively close to $90^{\circ}$; however, differences in the morphology of $\mathrm{IH}$ to $\mathrm{IH}: 1 \% \mathrm{Eu}$ were apparent. In sample with $1 \% \mathrm{Eu}$ the

exhibited by IH:xEu suggest that this material is a highly promising candidate for photoluminescent applications.

\section{Acknowledgements}

The authors thank the financial support of the Brazilian research financing institutions: FAPESP-CDMF 2013/07296-2, CNPq and CAPES. In memory of M. F. C. Abreu.

\section{References}

1. Cao AM, Hu JS, Liang HP and Wan LJ. Self-assembled vanadium pentoxide $\left(\mathrm{V}_{2} \mathrm{O}_{5}\right)$ hollow microspheres from nanorods and their application in lithium-ion batteries. Angewandte Chemie. 2005; 44(28):4391-4395. PMid:15942965. http:// dx.doi.org/10.1002/anie.200500946

2. Zhuang Z, Peng Q, Liu J, Wang X and Li Y. Indium hydroxides, oxyhydroxides, and oxides nanocrystals series. Inorganic Chemistry. 2007; 46(13):5179-5187. PMid:17530840. http:// dx.doi.org/10.1021/ic061999f

3. Lei ZB, Ma GL, Liu MY, You WS, Yan HJ, Wu GP et al. Sulfursubstituted and zinc-doped $\operatorname{In}(\mathrm{OH})_{3}$ : a new class of catalyst for photocatalytic $\mathrm{H}_{2}$ production from water under visible light illumination. Journal of Catalysis. 2006; 237(2):322-329. http://dx.doi.org/10.1016/j.jcat.2005.11.022

4. Yan T, Wang X, Long J, Liu P, Fu X, Zhang G et al. Urea-based hydrothermal growth, optical and photocatalytic properties of single-crystal line $\mathrm{In}(\mathrm{OH})_{3}$ nanocubes. Journal of Colloid and Interface Science. 2008; 325(2):425-431. PMid: 18555265. http://dx.doi.org/10.1016/j.jcis.2008.05.065

5. Avivi S, Mastai Y and Gedanken A. Sonohydrolysis of $\mathrm{In}^{3+}$ ions: formation of needlelike particles of indium hydroxide. Chemistry of Materials. 2000; 12(5):1229-1233. http://dx.doi. org/10.1021/cm9903677

6. Zhu HL, Yao KH, Zhang $\mathrm{H}$ and Yang DR. In $\mathrm{OOH}$ hollow spheres synthesized by a simple hydrothermal reaction. formation of a well-defined cube-like structure and a slight decrease were observed. It is speculated that europium at this concentration (1\%) promotes disorder in the IH matrix. This characteristic can be confirmed with an increase in the PL property observed in $\mathrm{IH}: 1 \%$ Eu as compared with the $\mathrm{IH}$ matrix. The increase in the europium concentration from $2 \%$ to $8 \% \mathrm{Eu}$ promotes reorganization of the system and an increase in the cube-like structure is again observed. A decrease in the IH matrix PL property was observed with an increase in the europium concentration, suggesting that the order in the system increases.

\section{Conclusions}

IH:xEu powders (where $\mathrm{x}=0,1,2,4$ and $8 \mathrm{~mol} \%$ ) were efficiently obtained in their crystalline phase using the MAH method at $140^{\circ} \mathrm{C}$ for $30 \mathrm{~min}$. The relative intensities of $\mathrm{Eu}^{3+}$ ion emissions increase as the concentration of this ion increases from 1 to $8 \mathrm{~mol} \%$ while in the IH matrix sample the luminescence intensity was drastically quenched. The mechanism that prevails in this case is the energy transfer from the $\mathrm{IH}$ matrix to $\mathrm{Eu}^{3+}$. These optical properties

Journal of Physical Chemistry B. 2005; 109(44):20676-20679. PMid:16853679. http://dx.doi.org/10.1021/jp0511911

7. Katoh R, Furube A, Yoshihara T, Hara K, Fujihashi G, Takano $\mathrm{S}$ et al. Efficiencies of electron injection from excited $\mathrm{N}_{3}$ dye into nanocrystalline semiconductor $\left(\mathrm{ZrO}_{2}, \mathrm{TiO}_{2}, \mathrm{ZnO}\right.$, $\mathrm{Nb}_{2} \mathrm{O}_{5}, \mathrm{SnO}_{2}, \mathrm{In}_{2} \mathrm{O}_{3}$ ) films. Journal of Physical Chemistry B. 2004; 108(15):4818-4822. http://dx.doi.org/10.1021/ jp031260g

8. Kim H, Horwitz JS, Kushto GP, Qadri SB, Kafafi ZH and Chrisey DB. Transparent conducting Zr-doped $\operatorname{In}_{2} \mathrm{O}_{3}$ thin films for organic light-emitting diodes. Applied Physics Letters. 2001; 78(8):1050-1052. http://dx.doi. org/10.1063/1.1350595

9. Shi Z, Wang W and Zhang Z. Synthesis and characterization of indium hydroxide truncated polyhedral microcrystals. Materials Letters. 2008; 62(27):4293-4295. http://dx.doi. org/10.1016/j.matlet.2008.07.006

10. Silva CC, Filho FP, Sombra ASB, Rosa ILV, Leite ER, Longo E et al. Study of structural and photoluminescent properties of $\mathrm{Ca}_{8} \mathrm{Eu}_{2}\left(\mathrm{PO}_{4}\right)_{6} \mathrm{O}_{2}$. Journal of Fluorescence. 2008; 18(2):253259. PMid:18049883. http://dx.doi.org/10.1007/s10895-0070242-9

11. Morais EA, Scalvi LVA, Tabata A, Oliveira JBB and Ribeiro SJL. Photoluminescence of $\mathrm{Eu}^{3+}$ ion in $\mathrm{SnO}_{2}$ obtained by solgel. Journal of Materials Science. 2008; 43(1):345-349. http:// dx.doi.org/10.1007/s10853-007-1610-1

12. Dutta DP, Sudarsan V, Srinivasu P, Vinu A and Tyagi AK. Indium oxide and europium/dysprosium doped indium oxide nanoparticles: Sonochemical synthesis, characterization, and photoluminescence studies. Journal of Physical Chemistry C. 2008; 112(17):6781-6785. http://dx.doi.org/10.1021/ jp800576y

13. Li B, Xie Y, Jing M, Rong G, Tang $\mathrm{Y}$ and Zhang $\mathrm{G}$. $\mathrm{In}_{2} \mathrm{O}_{3}$ hollow microspheres: synthesis from designed in $(\mathrm{OH})(3)$ precursors and applications in gas sensors and photocatalysis. Langmuir. 2006; 22(22):9380-9385. PMid:17042557. http:// dx.doi.org/10.1021/la061844k 
14. Zhu H, Wang $X$, Wang Z, Yang $C$, Yang $F$ and Yang $X$. Self-assembled 3D microflowery $\operatorname{In}(\mathrm{OH})(3)$ architecture and its conversion to $\operatorname{In}_{2} \mathrm{O}_{3}$. Journal of Physical Chemistry C. 2008; 112(39):15285-15292. http://dx.doi.org/10.1021/ jp804768w

15. Zhu H, Wang X, Yang F and Yang X. Template-free, surfactantless route to fabricate $\mathrm{In}(\mathrm{OH})_{3}$ monocrystalline nanoarchitectures and their conversion to $\operatorname{In}_{2} \mathrm{O}_{3}$. Crystal Growth \& Design. 2008; 8(3):950-956. http://dx.doi.org/10.1021/ $\operatorname{cg} 700850 \mathrm{e}$

16. Motta FV, Lima RC, Marques APA, Leite ER, Varela JA and Longo E. $\mathrm{In}_{2} \mathrm{O}_{3}$ microcrystals obtained from rapid calcination in domestic microwave oven. Materials Research Bulletin. 2010; 45(11):1703-1706. http://dx.doi.org/10.1016/j. materresbull.2010.06.056

17. Motta FV, Lima RC, Marques APA, Li MS, Leite ER, Varela JA et al. Indium hydroxide nanocubes and microcubes obtained by microwave-assisted hydrothermal method. Journal of Alloys and Compounds. 2010; 497(1-2):L25-L28. http://dx.doi. org/10.1016/j.jallcom.2010.03.069

18. Zhu HL, Wang NY, Wang L, Yao KH and Shen XF. In situ $\mathrm{X}$-ray diffraction study of the phase transition of nanocrystalline $\mathrm{In}(\mathrm{OH})_{3}$ to $\mathrm{In}_{2} \mathrm{O}_{3}$. Inorganic Materials. 2005; 41(6):609-612. http://dx.doi.org/10.1007/s10789-005-0178-x

19. Tang Q, Zhou WJ, Zhang W, Ou SM, Jiang K, Yu WC et al. Size-controllable growth of single crystal $\operatorname{In}(\mathrm{OH})(3)$ and $\operatorname{In}_{2} \mathrm{O}_{3}$ nanocubes. Crystal Growth \& Design. 2005; 5(1):147-150. http://dx.doi.org/10.1021/cg049914d

20. Zhu HL, Wang Y, Wang NY, Li Y and Yang J. Hydrothermal synthesis of indium hydroxide nanocubes. Materials Letters. 2004; 58(21):2631-2634. http://dx.doi.org/10.1016/j. matlet.2004.03.030

21. Koga $\mathrm{N}$ and Kimizu T. Thermal Decomposition of Indium(III) Hydroxide Prepared by the Microwave-Assisted Hydrothermal Method. Journal of the American Ceramic Society. 2008; 91(12):4052-4058. http://dx.doi.org/10.1111/ j.1551-2916.2008.02811.x

22. Chen LY, Zhang YG, Wang WZ and Zhang ZD. Tunable synthesis of various hierarchical structures of $\operatorname{In}(\mathrm{OH})(3)$ and $\mathrm{In}_{2} \mathrm{O}_{3}$ assembled by nanocubes. European Journal of Inorganic Chemistry. 2008; (9):1445-1451. http://dx.doi.org/10.1002/ ejic. 200700936

23. Wang L, Perez-Maqueda LA and Matijevic E. Rapid preparation of uniform colloidal indium hydroxide by the controlled double jet precipitation. Colloid and Polymer Science. 1998; 276(9):847-850. http://dx.doi.org/10.1007/ s003960050320

24. Perez-Maqueda LA, Wang LF and Matijevic E. Nanosize indium hydroxide by peptization of colloidal precipitates. Langmuir. 1998; 14(16):4397-4401. http://dx.doi.org/10.1021/ la980149c

25. Komarneni S, Roy $\mathrm{R}$ and Li QH. Microwavehydrothermal Synthesis of Ceramic Powders. Materials Research Bulletin. 1992; 27(12):1393-1405. http://dx.doi. org/10.1016/0025-5408(92)90004-J

26. Lima RC, Macario LR, Espinosa JWM, Longo VM, Erlo R, Marana NL et al. Toward an understanding of intermediateand short-range defects in $\mathrm{ZnO}$ single crystals: a combined experimental and theoretical study. Journal of Physical Chemistry A. 2008; 112(38):8970-8978. PMid:18652436. http://dx.doi.org/10.1021/jp8022474

27. Milao TM, Mendonça VR, Araujo VD, Avansi W, Ribeiro C, Longo E et al. Microwave hydrothermal synthesis and photocatalytic performance of $\mathrm{ZnO}$ and $\mathrm{M}: \mathrm{ZnO}$ nanostructures
( $\mathrm{M}=\mathrm{V}, \mathrm{Fe}, \mathrm{Co})$. Science of Advanced Materials. 2012; 4(1):5460. http://dx.doi.org/10.1166/sam.2012.1251

28. Moreira ML, Mambrini GP, Volanti DP, Leite ER, Orlandi MO, Pizani PS et al. Hydrothermal microwave: a new route to obtain photoluminescent crystalline $\mathrm{BaTiO}_{3}$ nanoparticles. Chemistry of Materials. 2008; 20(16):5381-5387. http://dx.doi. org/10.1021/cm801638d

29. Volanti DP, Keyson D, Cavalcante LS, Simões AZ, Joya $\mathrm{MR}$, Longo E et al. Synthesis and characterization of $\mathrm{CuO}$ flower-nanostructure processing by a domestic hydrothermal microwave. Journal of Alloys and Compounds. 2008; 459(12):537-542. http://dx.doi.org/10.1016/j.jallcom.2007.05.023

30. Sczancoski JC, Cavalcante LS, Joya MR, Varela JA, Pizani PS and Longo E. $\mathrm{SrMoO}_{4}$ powders processed in microwavehydrothermal: synthesis, characterization and optical properties. Chemical Engineering Journal. 2008; 140(13):632-637. http://dx.doi.org/10.1016/j.cej.2008.01.015

31. Araújo VD, Avansi W, Carvalho HB, Moreira ML, Longo E, Ribeiro $\mathrm{C}$ et al. $\mathrm{CeO}_{2}$ nanoparticles synthesized by a microwave-assisted hydrothermal method: evolution from nanospheres to nanorods. CrystEngComm. 2012; 14(3):11501154. http://dx.doi.org/10.1039/c1ce06188g

32. Sczancoski JC, Cavalcante LS, Marana NL, Silva RO, Tranquilin RL, Joya MR et al. Electronic structure and optical properties of $\mathrm{BaMoO}_{4}$ powders. Current Applied Physics. 2010; 10(2):614-624. http://dx.doi.org/10.1016/j. cap.2009.08.006

33. Motta FV, Marques APA, Li MS, Abreu MFC, Paskocimas CA, Bomio MRD et al. Preparation and photoluminescence characteristics of $\operatorname{In}(\mathrm{OH})_{3}: x \mathrm{~Tb}^{3+}$ obtained by MicrowaveAssisted Hydrothermal method. Journal of Alloys and Compounds. 2013; 553:338-342. http://dx.doi.org/10.1016/j. jallcom.2012.11.063

34. Xu X and Wang $X$. Size- and surface-determined transformations: from ultrathin $\mathrm{InOOH}$ nanowires to uniform $\mathrm{c}-\mathrm{In}_{2} \mathrm{O}_{3}$ Nanocubes and $\mathrm{rh}-\mathrm{In}_{2} \mathrm{O}_{3}$ nanowires. Inorganic Chemistry. 2009; 48(8):3890-3895. PMid:19326893. http:// dx.doi.org/10.1021/ic802449w

35. Chen L, Ma X, Liu Y, Zhang YG, Wang W, Liang Y et al. 3D architectures of InOOH: ultrasonic-assisted synthesis, growth mechanism, and optical properties. European Journal of Inorganic Chemistry. 2007; (28):4508-4513. http://dx.doi. org/10.1002/ejic.200700364

36. Chen SG, Huang YF, Cheng Y, Xia Q, Liao HW and Long CG. Shape-controlled growth of $\operatorname{In}(\mathrm{OH})_{3}$ crystals synthesized by diglycol-mediated solvothermal process. Materials Letters. 2008; 62(10-11):1634-1637. http://dx.doi. org/10.1016/j.matlet.2007.09.048

37. Canham LT. Silicon quantum wire array fabrication by electrochemical and chemical dissolution of wafers. Applied Physics Letters. 1990; 57(10):1046-1048. http://dx.doi. org/10.1063/1.103561

38. Xiong HM, Liu DP, Xia YY and Chen JS. Polyether-grafted ZnO nanoparticles with tunable and stable photoluminescence at room temperature. Chemistry of Materials. 2005; 17(12):30623064. http://dx.doi.org/10.1021/cm050556r

39. Fujihara S, Ogawa Y and Kasai A. Tunable visible photoluminescence from $\mathrm{ZnO}$ thin films through $\mathrm{Mg}$-doping and annealing. Chemistry of Materials. 2004; 16(15):29652968. http://dx.doi.org/10.1021/cm049599i

40. Draeger EW, Grossman JC, Williamson AJ and Galli G. Optical properties of passivated silicon nanoclusters: The role of synthesis. Journal of Chemical Physics, 2004; 120(22):1080710814. PMid:15268108. http://dx.doi.org/10.1063/1.1738633 
41. Wood DL and Tauc J. Weak absorption tails in amorphous semiconductors. Physical Review B. 1972; 5(8):3144-3151. http://dx.doi.org/10.1103/PhysRevB.5.3144

42. Chong MK, Pita K and Kam CH. Photoluminescence of sol-gel-derived $\mathrm{Y}_{2} \mathrm{O}_{3}: \mathrm{Eu}^{3+}$ thin-film phosphors with $\mathrm{Mg}^{2+}$ and $\mathrm{Al}^{3+}$ co-doping. Applied Physics A: Materials Science \& Processing. 2004; 79(3):433-437. http://dx.doi.org/10.1007/ s00339-004-2737-4

43. Rosa ILV, Marques APA, Tanaka MTS, Motta FV, Varela JA, Leite ER et al. Europium(III) Concentration effect on the spectroscopic and photoluminescent properties of $\mathrm{BaMoO}_{4}$ :Eu. Journal of Fluorescence. 2009; 19(3):495-500. PMid:19002571. http://dx.doi.org/10.1007/s10895-008-0438-7

44. Yu Y, Chen D, Wang Y, Huang P, Weng F and Niu M. Enhanced photoluminescence of Eu3+ induced by energy transfer from $\mathrm{In}_{2} \mathrm{O}_{3}$ nano-crystals embedded in glassy matrix. Physical
Chemistry Chemical Physics. 2009; 11(39): 8774-8778. PMid:20449022. http://dx.doi.org/10.1039/b907065f

45. Stavale F, Pascua L, Nilius N and Freund HJ. From embedded nanoislands to thin films: Topographic and optical properties of europium oxide on $\mathrm{MgO}(001)$ films. Physical Review B. 2012; 86(8). http://dx.doi.org/10.1103/PhysRevB.86.085448

46. Motta FV, Figueiredo AT, Longo VM, Mastelaro VR, Freitas AZ, Gomes L et al. Disorder-dependent photoluminescence in $\mathrm{Ba}_{0.8} \mathrm{Ca}_{0.2} \mathrm{TiO}_{3}$ at room temperature. Journal of Luminescence. 2009; 129(7):686-690. http://dx.doi. org/10.1016/j.jlumin.2009.01.014

47. Ding T, Zheng WT, Tian HW, Zang JF, Zhao ZD, Yu SS et al. Temperature-dependent photoluminescence in $\mathrm{La}_{2 / 3} \mathrm{Ca}_{1 / 3} \mathrm{MnO}_{3}$. Solid State Communications. 2004; 132(12):815-819. http:// dx.doi.org/10.1016/j.ssc.2004.09.047 